\title{
KONSENTRAT PROTEIN IKAN LELE DUMBO (Clarias gariepenus) AFKIR DALAM KERUPUK MELARAT UNTUK MENCAPAI SUSTAINABLE DEVELOPMENT GOALS
}

\author{
Sri Listyarini ${ }^{1}$ \\ Asriani2 $^{2}$ \\ Joko Santoso ${ }^{3}$ \\ 1FMIPA Universitas Terbuka \\ 2Pasca Sarjana Universitas Terbuka \\ 3Fakultas IImu Perikanan dan Kelautan IPB \\ e-mail: listyarini@ecampus.ut.ac.id
}

\begin{abstract}
At present the world is required to realize sustainable development, as outlined in the Sustainable Development Goals (SDGs). SDGs are 17 goals determined by the United Nations as a world development agenda for the benefit of humans and planet earth and are expected to be achieved in 2030. The first three SDGs are: first (poverty), second (hunger), and third (healthy and prosperous life). To achieve the 3 first goals of SDGs, a study on the production of fish protein concentrate (KPI) made from dumbo rejected catfish was conducted, and added the KPI catfish rejected concentrate to improve the quality of destitute crackers. The results of the study were: (1) the best KPI was made by extraction using $75 \%$ isopropyl alcohol (IPA) solvent, with 4 repetitions, the highest protein content was $78,71 \%$, the lowest fat content was 0,69\%, and the organoleptic value highest (4,37); and (2) the best destitute crackers are crackers with the addition of $10 \% \mathrm{KPI}$ with quality: $12,41 \%$ protein content, $28,5 \%$ florality, organoleptic value crispy texture, very weak savory taste, bright cream cracker color. The addition of KPIs derived from dumbo reject catfish in destitute crackers is expected to be used to achieve the objectives of the first SDGs up to the third, but further research is needed in the production scale with an analysis focus on economic aspects.
\end{abstract}

Keywords: Fish Protein Concentrate (KPI), Sustainable Development Goals (SDGs), dumbo African catfish, destitute crackers

\begin{abstract}
ABSTRAK
Saat ini dunia dituntut untuk mewujudkan pembangunan berkelanjutan, yang dituangkan dalam Sustainable Development Goals (SDGs). SDGs merupakan 17 tujuan yang ditentukan oleh PBB sebagai agenda dunia pembangunan untuk kemaslahatan manusia dan planet bumi dan diharapkan dapat dicapai pada tahun 2030. Tiga tujuan pertama SDGs adalah: pertama (kemiskinan), kedua (kelaparan), dan ketiga (Kehidupan sehat dan sejahtera). Untuk mecapai 3 tujuan SDGs ini dilakukan penelitian pembuatan konsentrat protein ikan (KPI) berbahan baku ikan lele dumbo afkir, dan menambahkan KPI lele dumbo afkir untuk meningkatkan kualitas kerupuk melarat. Hasil penelitian adalah: (1) KPI terbaik dibuat dengan ekstraksi menggunakan pelarut isopropil alkohol (IPA) konsentrasi $75 \%$, dengan 4 kali pengulangan, memiliki kadar protein yang paling tinggi $78,71 \%$, kadar lemak terendah 0,69\%, dan nilai organoleptik tertinggi $(4,37)$; dan (2) Kerupuk melarat terbaik
\end{abstract}


adalah kerupuk dengan penambahan KPI 10\% dengan kualitas: kadar protein 12,41\%, tingkat kemekaran $28,5 \%$, nilai organoleptik tekstur renyah, rasa gurih sangat lemah, warna kerupuk krem keputihan cemerlang. Penambahan KPI yang berasal dari lele dumbo afkir pada kerupuk melarat diharapkan dapat digunakan untuk mencapai tujuan SDGs pertama sampai dengan ketiga, namun diperlukan penelitian lebih lanjut dalam skala produksi dengan fokus analisis pada aspek ekonomi.

Kata kunci: Konsentrat Protein Ikan (KPI), Sustainable Development Goals (SDGs), ikan lele dumbo afkir, kerupuk melarat

Sustainable Development Goals (SDGs) adalah cetak biru (blue print) untuk mencapai masa depan yang lebih baik dan lebih berkelanjutan bagi semua. SDGs diharapkan dapat mengatasi tantangan global yang kita hadapi, termasuk yang terkait dengan kemiskinan, ketidaksetaraan, iklim, degradasi lingkungan, kemakmuran, serta perdamaian dan keadilan (United Nations, 2015). SDGs berupa 17 tujuan yang ditentukan oleh PBB sebagai agenda dunia pembangunan untuk kemaslahatan manusia dan planet bumi yang diharapkan dapat dicapai pada tahun 2030.

Tiga tujuan pertama SDGs adalah upaya mengatasi 1) kemiskinan dan 2) kelaparan untuk mencapai 3) kehidupan sehat dan sejahtera. Tiga tujuan pertama SDGs ini terkait dengan masalah kurang energi protein (KEP) yang masih merupakam masalah utama di bidang kesehatan. Di Indonesia masalah KEP ini belum seluruhnya terpecahkan, walaupun usaha perbaikan gizi keluarga oleh pemerintah maupun nonpemerintah sudah banyak dilakukan. Kurang energi protein (KEP) dapat terjadi akibat asupan makanan yang tidak mengandung energi dan protein serta karena adanya infeksi kronik atau berulang-ulang (Haslina, Muis, \& Suyatno, 2006). Salah satu cara mengatasi masalah KEP adalah dengan membuat konsentrat protein ikan (KPI) yang berasal dari ikan lele dumbo afkir.

Menurut Khairuman \& Khairul (2002) ikan lele dumbo memiliki kemampuan beradaptasi terhadap lingkungan yang tinggi, mempunyai rasa daging yang enak dan kandungan gizi yang tinggi. Ikan lele dumbo memiliki kadar protein cukup tinggi, yaitu 17,7-26,7\% dan lemaknya berkisar $0,95-11,5 \%$ (Nurilmala, Nurjanah, \& Utomo, 2009). Rosa, Bandara, \& Nunes (2007) menyatakan bahwa ikan lele dikelompokkan dalam bahan pangan berprotein sedang dengan lemak rendah. Ikan lele juga mengandung karoten, vitamin A, fosfor, kalsium, zat besi, vitamin B1, vitamin B6, vitamin B12, dan kaya asam amino. Menurut keterangan Rohimah, Etti, \& Ernawati (2014) kandungan komponen gizi ikan lele mudah dicerna dan diserap oleh tubuh manusia baik anak-anak, dewasa maupun orang tua.

Ikan lele dumbo pada umumnya dikonsumsi pada ukuran 6-8 ekor/kg. Jika lele dumbo sudah berukuran 2 -1 ekor/kg, apalagi yang ukurannya lebih dari $500 \mathrm{~g}$ per ekor, digolongkan sebagai lele dumbo ukuran jumbo dan pangsa pasarnya sangat terbatas, inilah yang dikatakan sebagai lele dumbo afkir. Ikan lele dumbo afkir jumlahnya mencapai 10\% dalam tiap siklus produksinya dan ikan lele afkir tidak laku dijual, kalaupun laku dijual dengan harga murah sehingga dapat merugikan pembudidaya (Khairuman \& Khairul, 2002). Salah satu peluang yang dapat dilakukan adalah dengan mengembangkan konsentrat protein ikan (KPI) untuk ditambahkan pada produk kerupuk melarat.

Konsentrat protein ikan (KPI) merupakan bahan pangan untuk konsumsi manusia, dengan jumlah protein yang dihasilkan lebih banyak dari kondisi awalnya karena terkonsentrasi (Windsor, 2001). KPI memiliki kadar protein tinggi dengan daya cerna yang tinggi pula. KPI terbagi pada tiga 
tipe, yaitu tipe $\mathrm{A}$ (kadar protein minimal $67,5 \%$ dan kadar lemak maksimal 0,75\%), tipe B (kadar protein minimal 67,5\% dan kadar lemak maksimal 3\%) dan tipe $\mathrm{C}$ (kadar protein minimal $67,5 \%$ dan kadar lemak maksimal 10\%) (Buckle, Edwards, Fleet, \& Wooton, 1987).

Kerupuk melarat adalah nama kerupuk khas yang banyak dijual di jalur Pantura Cirebon, disebut kerupuk melarat karena simbol orang miskin terlihat dari cara menggorengnya yang bukan menggunakan minyak (Prayitno, 2016). Bahan dasar kerupuk ini berupa tepung tapioka yang cukup dicampurkan garam, bawang putih, dan rempah-rempah lainnya, sehingga tidak mengandung protein. Penambahan KPI yang dibuat dari lele dumbo afkir diharapkan dapat meningkatkan nilai gizi protein kerupuk melarat, yang pada akhirnya dapat mencapai tujuan SDGs pertama sampai dengan ketiga.Tujuan penulisan artikel ini adalah untuk menjabarkan penelitian yang secara umum bertujuan untuk mencapai tujuan SDGs pertama (kemiskinan), kedua (kelaparan), dan ketiga (kehidupan sehat dan sejahtera) melalui penambahan KPI yang dibuat dari lele dumbo afkir pada kerupuk melarat. Secara khusus penelitian ini bertujuan untuk: (1) menganalisis metode pembuatan Konsentrat Protein Ikan (KPI) berbahan baku ikan lele dumbo afkir, dan (2) menganalisis penambahan KPI lele dumbo afkir terhadap kualitas kerupuk melarat.

\section{METODE}

Penelitian dilaksanakan pada bulan Februari sampai dengan Agustus tahun 2012 di Laboratorium Kimia dan Workshop Pengolahan Hasil di Sekolah Tinggi Perikanan Jakarta. Tahap pertama penelitian menggunakan Rancangan Acak Lengkap Pola Faktorial untuk pembuatan Konsentrat Protein Ikan (KPI). Rancangan Acak Lengkap Pola Faktorial ini menggunakan dua perlakuan yaitu penggunaan pelarut yang berbeda (etanol dan isopropil alkohol/ IPA) serta empat tahapan ekstraksi (1, 2, 3 dan 4 kali), dikeringkan menggunakan oven dengan suhu $40^{\circ} \mathrm{C}$ selama 8 jam dan ulangan dilakukan tiga kali. Variabel yang dianalisis meliputi kadar protein, kadar lemak, kadar air, dan nilai organoleptik.

Tabel 1. Rancangan Acak Lengkap Pola Faktorial untuk Pembuatan KPI

\begin{tabular}{lllll}
\hline \multirow{2}{*}{ Pelarut } & \multicolumn{4}{c}{ Ekstraksi } \\
\cline { 2 - 5 } & $1 \mathrm{x}$ & $2 \mathrm{x}$ & $3 \mathrm{x}$ & $4 \mathrm{x}$ \\
\hline isopropil alkohol (IPA) & A1 & A2 & A3 & A4 \\
etanol & B1 & B2 & B3 & B4 \\
\hline
\end{tabular}

Tahap kedua penelitian menggunakan Rancangan Acak Lengkap untuk pembuatan kerupuk melarat. Perlakukan yang digunakan sebanyak enam jenis yaitu persentase penambahan KPI yang berbeda 0\% (P1), 6\% (P2), 8\% (P3), 10\% (P4), 12\% (P5), dan 14\% (P6) dan ulangan dilakukan tiga kali. Variabel yang dianalisis meliputi kadar protein, tingkat kemekaran, daya terima konsumen kerupuk.

Tabel 2. Rancangan Acak Lengkap Komposisi Pembuatan Kerupuk Melarat

\begin{tabular}{lrrrrrr}
\hline \multirow{2}{*}{ Bahan (gram) } & \multicolumn{7}{c}{ Komposisi } \\
\cline { 2 - 7 } & P1 & P2 & P3 & P4 & P5 & P6 \\
\hline Tepung tapioka & 100 & 100 & 100 & 100 & 100 & 100 \\
KPI ikan lele & 0 & 6 & 8 & 10 & 12 & 14 \\
Garam & 3 & 3 & 3 & 3 & 3 & 3 \\
Bawang putih & 3 & 3 & 3 & 3 & 3 & 3 \\
\hline
\end{tabular}




\section{HASIL DAN PEMBAHASAN}

Sebelum dilakukan penelitian untuk membuat KPI, ikan lele dumbo afkir yang digunakan dalam penelitian dianalisis nilai gizinya. Hasil analisis proksimat komposisi ikan lele dumbo afkir dapat dilihat pada Tabel 3 .

Tabel 3. Komposisi Nilai Gizi Ikan Lele Dumbo (Clarias gariepinus)

\begin{tabular}{cc}
\hline Komposisi & Persentase $(\% \mathrm{~b} / \mathrm{b})$ \\
\hline Protein & $17,09 \pm 0,52$ \\
Lemak & $2,75 \pm 0,23$ \\
Air & $78,05 \pm 0,27$ \\
Abu & $1,25 \pm 0,50$ \\
Karbohidrat & $0,86 \pm 0,32$ \\
\hline
\end{tabular}

Kandungan protein ikan lele dumbo afkir tergolong tinggi yaitu 17,09\%. Menurut Handayani \& Kartikawati (2015) komposisi gizi ikan lele kandungan air 75,10\%, protein 18,79\%, lemak 4,03\%, dan mineral 2,08\%. Menurut Venugoval (2008) ikan yang tergolong berlemak rendah, jika kadar lemaknya kurang dari 3\%, berlemak sedang memiliki kadar lemak 3-5\% dan berlemak tinggi mempunyai kadar lemak lebih dari $7 \%$. Ikan lele dumbo termasuk ikan yang berlemak sedang dan kandungan proteinnya tinggi sehingga cocok diproses menjadi KPI.

Tahap pertama penelitian menghasilkan berbagai jenis KPI yang berbeda pelarut dan jumlah ekstraksinya. Hasil analisis KPI dapat dilihat pada Tabel 4. Nilai organoleptik aroma KPI lele afkir ditentukan dengan menggunakan uji skoring. Skor yang diberikan sebagai berikut: 1= aroma ikan sangat kuat, 2 = aroma ikan kuat, 3 = aroma ikan lemah, 4 = aroma ikan sangat lemah, 5 = tidak beraroma ikan. KPI yang bermutu baik memiliki nilai aroma ikan yang lemah saat diseduh dengan air panas.

Tabel 4. Hasil Analisis KPI

\begin{tabular}{lrrrrrrrr}
\hline \multirow{2}{*}{ Variabel } & \multicolumn{7}{c}{ Pelarut (A=IPA, B=Et) \& Jumlah Ekstraksi } \\
\cline { 2 - 9 } & \multicolumn{1}{c}{ A1 } & \multicolumn{1}{c}{ A2 } & \multicolumn{1}{c}{ A3 } & \multicolumn{1}{c}{ A4 } & \multicolumn{1}{c}{ B1 } & \multicolumn{1}{c}{ B2 } & \multicolumn{1}{c}{ B3 } & \multicolumn{1}{c}{ B4 } \\
\hline protein (\%) & 72,26 & 76,06 & 76,19 & 78,72 & 69,26 & 69,76 & 74,38 & 74,59 \\
kadar lemak (\%) & 10,68 & 3,30 & 2,57 & 0,68 & 15,91 & 12,15 & 7,64 & 6,26 \\
kadar air (\%) & 9,86 & 9,90 & 9,75 & 9,91 & 8,12 & 8,40 & 9,30 & 9,47 \\
nilai organoleptik (skor) & 1,00 & 1,87 & 3,23 & 4,37 & 1,00 & 1,33 & 1,90 & 3,20 \\
\hline
\end{tabular}

Hasil analisis terhadap KPI menunjukkan bahwa jenis pelarut berpengaruh sangat nyata terhadap kadar protein KPI. Hasil kadar protein KPI lele dumbo afkir (ukuran jumbo) yang diekstrak menggunakan pelarut IPA lebih tinggi dibanding dengan protein KPI lele dumbo yang diekstrak dengan menggunakan etanol. Kemampuan masing-masing pelarut untuk mengagregasi protein serta mengekstraksi lemak dan air berbeda, sehingga akan mempengaruhi kadar protein dan lemak KPI yang dihasilkan. Hal ini sesuai dengan pendapat McPhee \& Dubrow (1972), bahwa IPA merupakan pelarut yang baik dalam pembuatan KPI dibanding etanol. Penelitian Rieuwpassa, Santoso, \& Trilaksani (2013) menyatakan bahwa pelarut IPA menghasilkan kadar protein KPI yang lebih tinggi dibanding dengan pelarut etanol. Etanol adalah pelarut organik yang bersifat polar sehingga etanol 
tidak hanya melarutkan lemak dan air tetapi juga sedikit protein terlarut. Menurut Winarno (2008) etanol memiliki gugus hidroksil yang bersifat polar dan gugus metil yang bersifat non-polar sehingga sebagian kecil protein ikut terlarut. Makin banyak jumlah ekstraksi akan makin banyak jumlah protein pada KPI yang dihasilkan.

Analisis kadar lemak pada KPI menunjukkan bahwa penggunaan jenis pelarut berpengaruh sangat nyata terhadap penurunan kadar lemak KPI lele afkir. Kadar lemak rata-rata KPI yang terendah dibuat dengan menggunakan pelarut IPA (0,68\%). Menurut Tirtajaya, Santoso, \& Dewi (2008), kemampuan masing-masing pelarut untuk mengagregasi protein serta mengekstraksi lemak dan air berbeda sehingga akan mempengaruhi kadar protein dan lemak KPI yang dihasilkan. Pelarut alkohol merupakan pelarut organik bersifat polar yang memiliki kemampuan untuk memisahkan fraksi gula larut air dan lemak tanpa melarutkan proteinnya (Amoo, Adeboyo, \& Oyeleye, 2006).

Analisis kadar air terhadap KPI menghasilkan bahwa pengulangan ekstraksi tidak memberikan pengaruh nyata terhadap kadar air rata-rata KPI. Hal ini diduga karena ekstraksi dilakukan selama 20 menit per tiap kali ekstraksi sehingga kemampuan ekstraksinya rendah. Menurut Ibrahim (2009), KPI merupakan produk yang dihasilkan dengan cara menghilangkan lemak dan air. Kemampuan masing-masing pelarut untuk mengagregasi protein serta mengekstraksi lemak dan air yang dihasilkan berbeda.

Analisis terhadap uji nilai organoleptik KPI menyatakan bahwa hasil uji nilai tertinggi aroma $(4,37)$ diperoleh pada perlakuan ekstraksi dengan menggunakan pelarut IPA pada ulangan ekstraksi ke 4. Hasil ini sesuai dengan penelitian yang dilakukan oleh Rieuwpassa, Santoso, \& Trilaksani (2013) bahwa nilai tertinggi aroma yang diperoleh pada perlakuan ekstraksi menggunakan pelarut IPA dengan lama ekstraksi 3 jam. Proses ekstraksi bertujuan menghilangkan bau amis. Tujuan proses ekstraksi menggunakan alkohol, selain melarutkan kadar lemak juga bertujuan untuk mengurangi atau menghilangkan aroma amis ikan pada KPI. Semakin banyak lemak yang diekstrak semakin lemah aroma amis ikan, semakin tinggi nilai organoleptik aroma KPI. Proses ekstraksi tidak hanya mampu melarutkan lemak, akan tetapi juga menghilangkan material-material lain seperti darah, pigmen, dan bahan penyusun aroma (Rawdkuen, Samart, Khamsorn, Chaijan, \& Benjakul, 2009). Hal ini diduga karena selama ekstraksi lemak dan material lain ikut terekstraksi, sehingga bau amis ikan semakin kecil (skor organoleptik makin besar).

Tahap kedua penelitian berupa berbagai jenis kerupuk melarat dengan perbedaan pada jumlah KPI yang ditambahkan. Hasil analisis pada kerupuk melarat yang dihasilkan dapat dilihat pada Tabel 5.

Tabel 5. Hasil Analisis Kerupuk Melarat dengan Penambahan KPI

\begin{tabular}{lrrrrrr}
\hline \multirow{2}{*}{ Variabel } & \multicolumn{7}{c}{ Komposisi } \\
\cline { 2 - 7 } & \multicolumn{1}{c}{ P1 } & \multicolumn{1}{c}{ P2 } & \multicolumn{1}{c}{ P3 } & \multicolumn{1}{c}{ P4 } & \multicolumn{1}{c}{ P5 } & \multicolumn{1}{c}{ P6 } \\
\hline Protein (\%) & 1,24 & 9,10 & 11,38 & 12,41 & 14,10 & 14,80 \\
Tingkat kemekaran (\%) & 406,00 & 344,00 & 334,00 & 285,00 & 209,00 & 183,00 \\
Kerenyahan (skor) & 4,93 & 4,70 & 4,07 & 3,60 & 2,93 & 2,10 \\
Rasa (skor) & 1,90 & 2,40 & 2,06 & 2,36 & 2,26 & 2,26 \\
Warna (skor) & 4,80 & 4,36 & 4,26 & 4,06 & 4,13 & 4,13 \\
\hline
\end{tabular}


Penambahan KPI meningkatkan kandungan protein pada kerupuk melarat. Hal ini sesuai dengan penelitian Rieuwpassa \& Santoso (2014) yang menyatakan penambahan KPI meningkatkan kandungan protein pada makanan bayi pendamping ASI.

Analisis terhadap tingkat kemekaran (pengembangan volume) kerupuk dihitung dengan cara membandingkan volume kerupuk mentah dan kerupuk yang telah mengalami proses penggorengan dengan pasir. Tingkat pengembangan volume kerupuk terjadi pada proses penggorengan. Terjadinya pengembangan ini dapat disebabkan oleh terbentuknya rongga-rongga udara pada kerupuk yang telah digoreng karena pengaruh suhu, menyebabkan air yang terikat gel menjadi uap (Lavlinesia, 1995). Penggunaan tepung KPI mengakibatkan tepung tapioka sebagai sumber pati yang digunakan menjadi sedikit, sehingga lapisan berongga atau yang disebut kantung-kantung udara yang terbentuk semakin kecil dan terisi protein (Lavlinensia, 1995). Kandungan protein yang lebih tinggi cenderung menurunkan daya kembang kerupuk sehingga dapat menyebabkan kantung-kantung udara kerupuk yang dihasilkan semakin kecil karena padatnya kantung-kantung udara tersebut terisi bahan lain yaitu protein.

Analisis terhadap kerenyahan kerupuk dilakukan secara mutu hedonik dilakukan menggunakan skor dengan 5 skala kerenyahan, yaitu skor 1 (sangat tidak renyah), skor 2 (tidak renyah), skor 3 (agak renyah), skor 4 (renyah), skor 5 (sangat renyah). Kandungan protein yang tinggi cenderung menurunkan kerenyahan dan daya kembang kerupuk (Purnomo, Chalid, \& Bustaman, 1984). Protein terinteraksi dengan granula pati menghambat pengeluaran air, sehingga pada proses pengorengan kandungan air yang tertekan dan menguap akan semakin sedikit dan mengakibatkan pengembangan dan kerenyahan kerupuk menurun (Lavlinesia,1995).

Analisis terhadap rasa dilakukan secara organoleptik dan dinilai secara subyektif pada kerupuk dengan penambahan KPI. Skor yang diberikan sebagai berikut: $1=$ tidak berasa, 2 = rasa gurih sangat lemah, 3 = agak gurih, 4 = berasa gurih, 5 = sangat gurih. Hasil analisis menujukkan bahwa penambahan KPI tidak berpengaruh secara signifikan terhadap rasa gurih ikan pada kerupuk melarat. Hal ini kemungkinan disebabkan karena jumlah KPI yang ditambahkan relatif sedikit. Kerupuk yang divortifikasi KPI tidak berasa gurih ikan diduga disebabkan KPI yang ditambahkan kadar lemaknya kecil, rasa gurih ikan berasal dari lemak ikan. Selain itu, proses pengolahan kerupuk melarat yang ditambahkan bawang putih menyebabkan rasa gurih bawang putih lebih dominan dari pada rasa gurih $\mathrm{KPI}$.

Analisis terhadap warna dinilai secara subyektif dengan uji mutu hedonik. Skor yang diberikan sebagai berikut: 1= warna krem kusam, 2 = warna krem agak kusam, 3 = krem keputihan agak kusam, 4 = krem keputihan cerah, 5 = warna putih cerah. Hasil analisis menunjukkan bahwa perlakuan penambahan KPI tidak berpengaruh signifikan terhadap warna kerupuk melarat. Hal ini disebabkan KPI yang ditambahkan warnanya putih dengan derajat putih 85 sehingga tidak memberikan efek warna pada produk kerupuk. Padahal Syahrul (2009) menyatakan warna merupakan hal yang penting bagi makanan, baik yang diproses maupun tanpa proses.

Tahap pertama dan kedua penelitian ini diharapkan dapat mengurangi tingkat kemiskinan (SDGs pertama) karena peternak lele dumbo masih dapat menjual lele afkir (berukuran jumbo) dan produsen kerupuk melarat dapat meningkatkan kualitas dan kuantitas kerupuk. Hasil penelitian ini juga diharapkan dapat meminimalkan jumlah masyarakat yang kelaparan (SDGs kedua) dalam kaitannya dengan KEP (kekurangan energi protein), mengingat penambahan KPI dari lele dumbo afkir dapat meningkatkan kadar protein kerupuk melarat. Pada akhirnya diharapkan penambahan KPI dari lele dumbo afkir dapat meningkatkan kehidupan sehat dan sejahtera (SDGs ketiga), karena kecukupan protein pada makanan dan peningkatan pendapatan peternak lele dumbo dan produsen 
kerupuk melarat. Penelitian ini dilakukan dalam skala laboratorium. Oleh karena itu penelitian penambahan KPI dari lele dumbo afkir pada adonan kerupuk melarat dalam kaitannya untuk mencapai tujuan SDGs pertama sampai dengan ketiga masih perlu diteliti lebih lanjut dalam skala produksi dengan analisis yang lebih mendalam pada faktor ekonomi.

\section{SIMPULAN}

Metode terbaik dalam pembuatan KPI lele afkir adalah dengan ekstraksi menggunakan pelarut isopropil alkohol (IPA) konsentrasi 75\%, dengan 4 kali pengulangan, memiliki kadar protein yang paling tinggi $78,71 \%$, kadar lemak terendah $0,69 \%$ dan nilai organoleptik tertinggi (4,37). KPI yang dihasilkan dalam penelitian ini tergolong KPI tipe A. Perlakuan P4 (penambahan KPI 10\%) dapat dikatakan sebagai kerupuk yang terbaik dengan: kadar protein $12,41 \%$, yang memenuhi persyaratan SNI kerupuk 2009 yaitu 5\%; tingkat kemekaran 28,5\%; nilai organoleptik tekstur renyah; rasa gurih sangat lemah; warna kerupuk krem keputihan cemerlang.

\section{REFERENSI}

Amoo, I.A, Adebayo, O.T, \& Oyeleye, AO. (2006). Chamical evaluation of winged beans (Psophocarous tetragonolabus), pitanga cherries (Eugenia uniflora) and orchid fruit (Orchid fruit myristica). African.J Food Agric.Nutr.Dev, 6(2):1-12.

Buckle, K.A., Edwards, R.A., Fleet, G.H., \& Wooton, M. (1987). IImu Pangan. Diterjemahkan oleh Purnomo, H., Adiono. Jakarta: UI Press.

Handayani D.W., \& Kartikawati D. (2015). Stiklele alternatif diversifikasi olahan lele (Clarias SP) tanpa limbah berkalsium tinggi. Jurnal IImiah UNTAG Semarang, 4(1): 109-117.

Haslina, Muis, S.F., \& Suyatno. (2006). Nilai gizi, daya cerna protein dan daya terima patilo sebagai makanan jajanan yang diperkaya dengan hidrolisat protein ikan mujair. Jurnal Gizi Indonesia. 1(2):34-40.

Ibrahim, M.S. (2009). Evaluation of production and quality of salt biscuits supplemented with fish protein concentrate. World J Dairy Food Sciences, 4(1): 28-31.

Khairuman \& Khairul, A. (2002). Bududaya ikan di sawah. Jakarta: Agromedia Pustaka.

Lavlinesia. (1995). Kajian beberapa faktor pengembangan volumetrik dan kerenyahan kerupuk ikan (tesis). Bogor: Progam Pasca Sarjana, Institut Pertanian Bogor.

McPhee, A.D, \& Dubrow, D.L. (1972). Application of ternary equilibrium data to the production of fish protein concentrate. J Amarecan Oil chem., Soc.49(9):501-504.

Nurilmala, M., Nurjanah, \& Utama, R.H. (2009). Kemunduran mutu ikan lele dumbo. Jurnal Pengolahan Hasil Perikanan Indonesia. 12 (1) 1-16.

Prayitno, P. (2016). Nama Awal Kerupuk Melarat Khas Pantura Cirebon. Diakses pada 26 September 2018 dari https://www.liputan6.com/regional/read/2544255/nama-awal-kerupuk-melaratkhas-pantura-cirebon.

Purnomo, A.H., A. Chalid, \& S. Bustaman. (1984). Prelimary Study on Preparation of Kerupuk Ikan. Laporan Penelitian Teknologi Perikanan, 38: 17-21.

Rawdkuen, S., S.U. Samart, S. Khamsorn, M. Chaijan, \& S. Benjakul. (2009). Biochemical and gelling propertties of Tilapia Surimi and protein recovered using an acid-alkaline process. Food Chemistry, 112:112-119. 
Rieuwpassa, F. \& Santoso, J. (2014). Karakeristik sifat fungsional konsentrat protein telur ikan Cakalang (Katsuwonus pelamis) serta aplikasinya dalam formulasi makanan bayi pendamping ASI. Tesis Sekolah Pascasarjana Institut Pertanian Bogor.

Rieuwpassa, F., Santoso, J., \& Trilaksani, W. (2013). Karakeristik sifat fungsional konsentrat protein telur ikan Cakalang (Katsuwonus pelamis). Jurnal IImu dan Teknologi Kelautan Tropis, 5 (2): 299-309.

Rohimah, I., Etti, S., \& Ernawati, N. (2014). Analisis energi dan protein serta daya terima biskuit tepung labu kuning dan ikan lele. Jurnal USU. Diakses pada 26 September 2018 dari https://jurnal.usu.ac.id/index.php/gkre/article/view/5160/2781.

Rosa, R., Bandara, N.M, \& Nunes, M.I. (2007). Nutritional quality of African cat fish Clarias gariepinus (Burchell 1822): A positive criterion for the future developmant of Siluroidei, Journal Food Science and Technology, 42:342-351.

Syahrul (2009). Study komperatif mutu pikel Eucheuma cottonii yang menggunakan asam asetat dan asam laktat hasil fermentasi rebung. Jurnal Penelitian Pertanian BERNAS, 52:44-55.

Tirtajaya, I., Santoso, J. \& Dewi, K. (2008). Pemanfaatan konsentrat protein ikan Patin (Pangasius pangasius) pada pembuatan cookies coklat. J Ilmu teknologi Pangan, 6(2): 87-103.

United Nations. (2015). About the Sustainable Development Goals. Diakses pada 3 September 2018 dari https://www.un.org/sustainabledevelopment/sustainable-development-goals/.

Venugoval, V. (2008). Seafood processing; adding value through quick freezing retortable packaging and cook-chilling. New York: Taylor dan Prancis.

Winarno, F.G. (2008). Kimia Pangan dan Gizi. Bogor: M. Brio Press.

Windsor, ML. (2001). Fish protein concentrate. Minestri of Technology Torry Researh Station. Torry Advisory Note No 39. Diakses pada 3 September 2018 dari http://www.fao.org/wairdocs/tan/x5917e/x5917e01.htm. 